\title{
HUBUNGAN SENAM ASMA TERHADAP KUALITAS PASIEN ASMA DI RUMAH SAKIT UMUM KABUPATEN TANGERANG
}

\author{
*Kusniawati, *Siti Wasliyah
}

\begin{abstract}
ABSTRAK
Kualitas hidup merupakan persepsi individu atas posisinya dalam kehidupan dengan system social dan system nilai di lingkungannya dan dalam hubungannya dengan target, pengharapan, standard dan kepentingan pasien. Penilitian ini bertujuan untuk mengidentifikasi hubungan senam asma dengan kualitas hidup pasien asma di Rumah Sakit Umum Kabupaten Tangerang. Penilitian korelasi dengan desain cross sectional, jumlah sampel 30 responden dengan teknik pengambilan yaitu quota sampling, pengumpulan data menggunakan kuesioner. Analisis stastistik menggunakan uji chi square. Hasil analisis menunjukan bahwa ada hubungan antara senam asma dengan kualitas hidup pasien asma ( $\mathrm{p}=0,000 ; \alpha$ $=0,05)$. Senam asma dapat di gunakan sebagai intervensi mandiri dalam manajemen asuhan keperawatan pasien asma.
\end{abstract}

Kata kunci : kualitas hidup, asma

*Poltekkes Kemenkes Banten 


\begin{abstract}
ABSTRACK
Quality of life is an individual perception of their position in life with the social system and system of values in the environment and in relation to the targets, expectations, standards and interests of patients. This research aims to identify the relationship gymnastics asthma with quality of life of patients with asthma in Tangerang General Hospital. This Research is correlation with cross-sectional design, the sample size of 30 respondents to the capture technique that is quota sampling, data collection using the questionnaire. Statistical analysis using chi square test. Results of the analysis showed that there is a relationship between asthma gymnastics with the quality of life of patients with asthma $(p=0.000 ; \alpha=$ 0.05). Gymnastics asthma can be used as a standalone intervention in the management of nursing care of patients with asthma.
\end{abstract}

Keywords: quality of life, asthma 


\section{Pendahuluan}

Asma merupakan penyakit gangguan inflamasi kronis saluran pernafasan yang dihubungkan dengan hiperresponsif, keterbatasan aliran udara yang reversible dan gejala pernafasan yang meliputi bunyi nafas wheezing, dyspnoe, batuk, dada merasa sesak, tachypnoe dan tachycardia (Sudoyo, 2006). Istilah asma berasal dari kata yunani yang artinya terengahengah dan berarti serangan nafas pendek, yang menunjukkan respon abnormal saluran nafas terhadap berbagai rangsangan yang menyebabkan penyempitan jalan nafas yang meluas, yang disebabkan oleh bronkospasme, edema mukosa dan hipersekresi mukus yang kental bersifat kambuh, berulang dan reversible (Price \& Wilson, 2005).

Menurut data badan kesehatan dunia (WHO) tahun 2006, sebanyak 300 juta orang menderita asma dan diperkirakan pada tahun 2025 jumlah penderita asma mencapai 400 juta orang. Selain itu sebanyak 255.000 jiwa diperkirakan meninggal dunia karena asma diseluruh dunia (Sundaru, 2007). Penyakit asma termasuk dalam lima besar penyebab kematian di dunia yang bervariasi sekitar 5$30 \%$ (berkisar 17,4\%). Di Indonesia asma termasuk dalam sepuluh besar penyebab kesakitan dan kematian di Rumah Sakit, dimana diperkirakan $10 \%$ dari 25 juta penduduk Indonesia menderita asma, prevalensi kejadian asma pada tahun 2010 sebesar 3,32\% (Oemiati, Sihombing \& Qomariah, 2010). Peningkatan jumlah penderita penyakit asma tersebut dikarenakan oleh kontrol penyakit asma yang buruk serta sikap penderita penyakit asma yang sering meremehkan tingkat keparahan (Siswono, 2007).

Senam asma merupakan salah satu manajemen dalam penatalaksanaan pasien asma. Senam asma adalah suatu jenis latihan yang dilakukan secara berkelompok yang melibatkan aktifitas gerakan-gerakan anggota tubuh dengan tujuan untuk meningkatkan kesegaran jasmani dan meningkatkan kemampuan bernapas.

Hasil penelitian Widiarti Rini (2011) menjelaskan bahwa latihan pernafasan perut (diaphragmatic breathing exercise) dapat meningkatkan kualitas hidup penderita asma. Hasil penelitian Ikalius, et al (2007) menjelaskan bahwa rehabilitasi paru menyebabkan perubahan kualitas hidup dan kapasitas fungsional penderita Penyakit Paru Obstruktif Menahun (PPOK). Sementara hasil penelitian Widjanegara Gede (2014) menjelaskan bahwa pemberian pelatihan senam asma sebanyak tiga kali seminggu selama delapan minggu dapat menurunkan frekuensi kekambuhan dan meningkatkan saturasi oksigen pada penderita asma $(\mathrm{p}=0,001)$. 
Penelitian lain dilakukan oleh Imelda, et al (2007) menunjukkan hasil bahwa derajat asma mempengaruhi kualitas hidup pada kelompok asma derajat ringan dibandingkan derajat sedang dan berat tetapi tidak mempengaruhi kualitas hidup pada kelompok asma derajat sedang dibandingkan derajat berat.

Kualitas hidup adalah persepsi individu atas posisinya dalam kehidupan dengan sistem sosial dan system nilai di lingkungannya dan dalam hubungannya dengan target, pengharapan, standar dan kepentingan pasien.

\section{Metoda}

Penelitian ini merupakan penelitian korelasi menggunakan desain cross sectional. Instrumen dalam penelitian ini menggunakan kuesioner untuk menggali karakteristik responden sedangkan untuk menilai kualitas hidup pasien asma menggunakan modifikasi kuesioner MAQLQ (Mini Asthma Quality of life Questionnnaire) yang dikembangkan oleh Junifer terdiri dari 15 pernyataan meliputi 11 pernyataan berhubungan dengan aspek fisik dan 4 pernyataan berhubungan dengan aspek aktifitas. Populasi dan sampel dalam penelitian ini adalah pasien asma yang berobat di poliklinik paru Rumah Sakit Umum Kabupaten Tangerang.

\section{Hasil}

Analisis Univariat

Tabel 1.

Distribusi Responden Berdasarkan Jenis kelamin, Pendidikan, Pekerjaan, Tingkat Kualitas Hidup dan senam asma

\begin{tabular}{|l|l|c|c|}
\hline No & Variabel & F & $\%$ \\
\hline 1. & Jenis Kelamin : & & \\
& - Laki-laki & 16 & 26,7 \\
& - Perempuan & 44 & 73,3 \\
\hline 2. & Pendidikan & & \\
& - SD & 32 & 53,3 \\
& - SLTP & 6 & 10,0 \\
& - SLTA & 12 & 20,0 \\
& - Akademi & 10 & 16,7 \\
\hline 3. & Pekerjaan & & \\
& - IRT & 47 & 78,3 \\
& - PNS & 3 & 5,0 \\
& - Swasta & 5 & 8,3 \\
& - Pensiunan & 4 & 6,7 \\
& - Petani & 1 & 1,7 \\
\hline 4. & Tingkat kualitas & & \\
& hidup & 28 & 46,7 \\
& - Tinggi & 32 & 53,3 \\
& - Rendah & & \\
\hline 5. & Senam asma & & \\
& - Ya & 30 & 50 \\
& - Tidak & 30 & 50 \\
\hline
\end{tabular}

Tabel 1 menunjukkan bahwa sebagian besar responden berjenis kelamin perempuan (73,3\% ), memiliki pendidikan SD $(53,3 \%)$, bekerja sebagai ibu rumah tangga $(78,3 \%)$, memiliki kualitas hidup rendah $(53,3 \%)$ dan responden yang melakukan kegiatan senam dan tidak senam sebesar $50 \%$. 


\section{Analisis Bivariat}

Tabel 2

Distribusi Responden Berdasarkan Umur, Berat Badan, Lama Sakit dan Frekuensi Serangan Asma ( $\mathrm{n}=60)$

\begin{tabular}{llllll}
\hline $\begin{array}{c}\mathrm{N} \\
\mathrm{o}\end{array}$ & Variabel & Mean & SD & $\begin{array}{l}\text { Mini } \\
\text { mal- } \\
\text { Maks } \\
\text { imal }\end{array}$ & $\begin{array}{l}95 \% \\
\mathrm{CI}\end{array}$ \\
\hline 1. & Umur & 57,53 & 12,06 & $30-73$ & $54,42-$ \\
& & & & 60,65 \\
\hline 2. & $\begin{array}{l}\text { Berat } \\
\text { Badan }\end{array}$ & 61,82 & 12,62 & $44-80$ & $58,56-$ \\
& & & & 65,08 \\
\hline 3. & Lama & 13,69 & 12,89 & $0,7-40$ & $10,36-$ \\
& sakit & & & & 17,01 \\
& asma & & & & \\
\hline 4. & $\begin{array}{l}\text { Frekuensi } \\
\text { serangan }\end{array}$ & 2,95 & 3,34 & $1-14$ & $2,09-$ \\
& & & & 3,81 \\
\hline
\end{tabular}

Tabel 2 menunjukkan bahwa rata-rata umur responden adalah 57,53 tahun. Hasil estimasi interval dapat disimpulkan bahwa rata-rata umur pasien asma yang berobat di poliklinik Penyakit Dalam Rumah Sakit Umum Kabupaten Tangerang adalah 54,42 tahun sampai dengan 60,65 tahun.

Rata-rata berat badan pasien asma adalah 61,82 kg. Hasil estimasi interval dapat disimpulkan bahwa rata-rata berat badan pasien asma yang berobat di poliklinik Penyakit Dalam Rumah Sakit Umum Kabupaten Tangerang adalah 58,56 kg sampai dengan 65,08 kg. Rata-rata lama sakit asma responden adalah 13,69 tahun. Hasil estimasi interval dapat disimpulkan bahwa rata-rata lama sakit pasien asma yang berobat di poliklinik Penyakit Dalam Rumah Sakit Umum Kabupaten Tangerang adalah 10,36 tahun sampai dengan 17,01 tahun. Rata-rata frekuensi serangan asma responden adalah 2,95 kali dalam sebulan. Hasil estimasi interval dapat disimpulkan bahwa rata-rata frekuensi serangan asma pada pasien asma yang berobat di poliklinik Penyakit Dalam Rumah Sakit Umum Kabupaten Tangerang adalah 2,09 sampai dengan 3,81 kali dalam sebulan.

\section{Tabel 3}

Distribusi Responden Menurut senam asma dan kualitas hidup ( $\mathrm{n}=60)$

\begin{tabular}{|c|c|c|c|c|c|c|c|c|}
\hline \multirow{3}{*}{$\begin{array}{l}\text { Senam } \\
\text { asma }\end{array}$} & \multicolumn{4}{|c|}{ Kualitas hidup } & \multirow{2}{*}{\multicolumn{2}{|c|}{ Total }} & \multirow{3}{*}{$\begin{array}{l}\text { P } \\
\text { Value }\end{array}$} & \multirow{2}{*}{$\begin{array}{l}\text { OR } \\
(95 \% \\
\text { CI }\end{array}$} \\
\hline & \multicolumn{2}{|c|}{ Rendah } & \multicolumn{2}{|c|}{ Tinggi } & & & & \\
\hline & $\mathrm{n}$ & $\%$ & $\mathrm{n}$ & $\%$ & $\mathrm{n}$ & $\%$ & & \\
\hline Tidak & 248 & 80,0 & 6 & 20,0 & 30 & 100 & 0,000 & 113,29 \\
\hline Ya & & 26,7 & 22 & 73,3 & 30 & 100 & & $-36,75$ \\
\hline Jumlah & 32 & 53,3 & 28 & 46,7 & 60 & 100 & & \\
\hline
\end{tabular}

Tabel 3 menunjukkan bahwa hasil analisis hubungan antara senam asma dengan kualitas hidup diperoleh bahwa kualitas hidup rendah lebih banyak terjadi pada pasien asma yang tidak melakukan senam asma $(80 \%)$.

Hasil uji statistik diperoleh nilai $\mathrm{p}=0,000$ maka dapat disimpulkan bahwa terdapat perbedaan proporsi kualitas hidup pasien asma antara pasien yang tidak melakukan senam asma dan yang melakukan senam asma (ada hubungan 
yang signifikan antara senam asma dengan kualitas hidup). Dari hasil analisis diperoleh nilai $\mathrm{OR}=11$, hal ini menunjukkan bahwa pasien yang tidak melakukan senam asma memiliki peluang 11 kali untuk memiliki kualitas hidup rendah dibandingkan dengan pasien yang melakukan senam asma.

\section{Pembahasan}

1. Jenis kelamin

Menurut Alsagaf dan Mukty (2008) Perbandingan angka kejadian asma berdasarkan jenis kelamin antara laki-laki dan perempuan adalah 1,5:1. Serangan asma pada orang dewasa dimulai pada umur lebih dari 35 tahun dan wanita lebih banyak daripada laki-laki. Hasil penelitian ini sejalan dengan hasil penelitian yang dilakukan oleh Imelda Syifa (2007) bahwa lebih banyak perempuan yang menderita asma $(77,7 \%)$. Hal ini sejalan juga dengan hasil penelitian Widjanegara (2014) yang menjelaskan bahwa dari tiga puluh sampel penelitian tentang pengaruh senam asma terhadap kekambuhan dan saturasi oksigen diperoleh hasil bahwa $56,7 \%$ responden memiliki jenis kelamin perempuan. Angka kejadian asma pada anak laki-laki usia 2-5 tahun adalah dua kali lebih sering dibandingkan dengan anak perempuan pada usia yang sama akan tetapi pada usia 20 tahun keatas, angka kejadian asma pada perempuan lebih sering dibandingkan dengan laki-laki (Amu, 2006).

\section{Pendidikan}

Tingkat pendidikan sangat berpengaruh terhadap kejadian asma. Persentase tertinggi penderita asma terjadi pada kelompok penduduk yang tidak sekolah (7,5\%) (Oemiati, 2010).

\section{Umur}

Pada pasien penderita asma terdapat tiga perubahan paru secara fisiologis yaitu penurunan kekuatan otot pernafasan, penurunan elastic recoil paru dan peningkatan kekakuan dinding dada. Pada pasien usia lanjut mudah terjadi serangan asma yang lebih berat selain itu faktor yang harus diperhatikan pada pasien asma yang berusia lanjut adalah lamanya perjalanan penyakit (Vignola, 2003). Serangan asma pada orang dewasa dimulai pada umur lebih dari 35 tahun (Alsagaf dan Mukty, 2008)

\section{Berat badan}

Indikator berat badan yang berhubungan dengan asma adalah obesitas. Obesitas dapat menurunkan daya pengembangan paru, volume paru dan diameter saluran pernafasan perifer serta mempengaruhi volume darah di paru (Delgado et al, 2008). Frekuensi asma lebih sering terjadi pada seseorang dengan obesitas (GINA, 2012). Semakin besar indeks masa tubuh maka semakin baik kualitas hidup pasien yang dinilai dengan 
menggunakan AQLQ. Pasien asma dengan indeks masa tubuh lebih besar mempunyai derajat asma dan gejala asma yang lebih berat dibandingkan dengan pasien asma yang mempunyai indeks massa tubuh normal (Imelda Syifa, et al, 2007).

\section{Frekuensi serangan asma}

Peningkatan frekuensi serangan asma ditinjau dari dimensi emosional akan meningkatkan rasa cemas dan depresi bagi pasien. Hal ini akan menimbulkan kegelisahan membayangkan serangan asma mendadak akan terjadi pada diri pasien.

\section{Kualitas hidup}

Kualitas hidup adalah persepsi individu mengenai posisinya dalam lingkup budaya dan sistem nilai di tempat hidup, serta dalam hubungan dengan tujuan, harapan dan standar yang dianut (WHO, 2007). Pengukuran kualitas hidup dapat berbedabeda yang meliputi domain kesehatan, aktivitas, sosial, emosi dan lain-lain (Taylor et al, 2000)

7. Hubungan senam asma terhadap kualitas hidup

Senam asma merupakan salah satu teknik pernafasan abdomen akan dapat meningkatkan udara ekspirasi. Pernafasan abdomen identik dengan pernafasan diafragmatik yang bermanfaat untuk meningkatkan dan menguatkan diafragma selama pernafasan untuk mencapai peningkatan tekanan intra abdominal
(Brunner \& Suddarth, 2006). Senam asma adalah suatu cara untuk melatih teknik bernafas yang efektif pada pasien asma selain itu merupakan salah satu penunjang pengobatan asma karena keberhasilan pengobatan asma tidak hanya ditentukan oleh obat asma yang dikonsumsi akan tetapi ditentukan juga oleh gizi dan olahraga.

Senam asma dapat berpengaruh terhadap kualitas hidup pasien asma. Hasil peneltian ini sejalan dengan hasil penelitian Windarti (2010) dalam jurnal dengan judul pengaruh diaphragmatic breathing exercise terhadap peningkatan kualitas hidup penderita asma. Dalam penelitian ini skor kualitas hidup sebelum dilakukan diaphragmatic breathing exercise adalah 41 sampai dengan 69, sedangkan skor kualitas hidup setelah dilakukan diaphragmatic breathing exercise adalah 71 sampai 84, sehingga dapat disimpulkan bahwa diaphragmatic breathing exercise dapat meningkatkan kualitas hidup penderita asma.

\section{Simpulan}

1. Sebagian besar responden berjenis kelamin perempuan, berpendidikan SD, bekerja sebagai ibu rumah tangga, memiliki kualitas hidup rendah, umur rata-rata responden 57,53 tahun, rata-rata berat badan $61,82 \mathrm{~kg}$, rata-rata lama sakit asma 13,69 tahun, dan rata-rata 
frekuensi serangan asma 2,95 kali dalam sebulan.

2. Kualitas hidup rendah lebih banyak terjadi pada penderita asma yang tidak melakukan senam asma dibandingkan dengan pasien yang melakukan senam asma.

\section{Daftar Pustaka}

Amu FA, Yunus F (2006). Asma pra menstruasi. Departemen Pulmonologi Respirasi FKUI RS Persahabatan. Jakarta

Alsagaf dan Mukty. (2008). Dasar-dasar ilmu penyakit paru. $5^{\text {th }}$ ed. Airlangga university press. Surabaya

Imelda Syifa, Yunus Faisal dan Wiyono Wiwien Heru. (2007). Hubungan derajat asma dengan kualitas hidup yang dinilai dengan asthma quality of life questionnaire. Majalah Kedokteran Indonesia, Volume: 57 .

Brunner \& Suddarth. (2006). Buku ajar keperawatan medical bedah. Edisi 8 . Volume 1. EGC. Jakarta

Delgado et al. (2008). Autophagy in immunity against mycobacterium tuberculosis

GINA. (2012). Global Strategy for asthma managemen and prevention. Global initiative for asthma (online). Available from http//.ppdi.org.html

Junifer, E.F; Guyatt, G.H; Cox, F.M et all. (1999). Development and validation of the mini asthma quality of life questionnaire. Europian Respiratory Journal 